Barbara L.El Mohandes

English Language Consultant,

Parasitic Acarine Project \& PARC,

Faculty of Agriculture, Cairo University

The First International Conference of

The Faculty of Al-Alsun, Minia University

Egypt in World Literature

$14-15$ April 2004

\title{
Is it True that East is East and West is West and Never the Twain Shall Meet?
}

I think I need to introduce my subject with a short preface. The theme of this Conference is Egypt in World Literature and so there have been queries as to why differing cultural aspects of Egypt and America should be examined at this time. The answer is rather like the reply to the question of why bother with so much emphasis on teaching language and linguistics when the students should be reading literature. And so I ask, how can he read literature when his language skills are inadequate for him to understand the essence of the matter at hand? And how can anyone understand literature if the very nature of the culture under the microscope is ill understood?

This paper itself is in no way strictly scientific, but more a matter of my own experience and experiences over the many years I have been fortunate enough to live in Egypt. Therefore, I excuse myself in advance for any errors in conception or even of fact. This is a personal history of my own observations and thought.

That said, let's look at our title and set up the parameters for our discussion.

"Oh, East is East, and West is West and never the twain shall meet, Till Earth and Sky stand presently at God's great Judgement Seat"

from The Ballad of East and West, by Rudyard Kipling. "This is a phrase (from the ballad) which emphasizes the divergence of views on ethics and life in general between the Oriental and Western peoples" (Brewer, 1970). Does this dissimilarity, indicating an essential lack of resemblance between things in some respects comparable, exist between Egypt and America, today?

Okay, so let's take a look at some habitual activities that occur in both societies; perhaps it would be more accurate to say, in all societies. I think it is a fair assessment of humankind to assert that all of us, whatever race or nation we belong to, are basically made of the same stuff? We learn, we work, we eat and sleep, we marry, we raise children and care for them, we all wish to improve our 
lives, we play and we pray. So, in what way can you see that in this very list, the priorities are western oriented and not Egyptian? Correct. If it were an Egyptian list of daily human activities, it would have started and ended with "we pray".

I should like to advise you that this paper is in no way intended to be negatively critical or judgmental of either Egyptian or American culture, their way of life, their traditions. I come before you loving both countries and both peoples, both Ta'amia bi Tahina and hotdogs with mustard. Which is better? Both are delicious and nutritious.

Actually, there are a couple of amusing little tidbits here. As you all know McDonald's has set up in Egypt in a big way selling its hamburgers and French fries to a widening group of people who want to sample the American way of eating. When I was in New York City several years ago, I took some Egyptian friends to Wall Street to visit The New York Stock Exchange, that bastion of American financial power. And what did we find in front of its main entrance, but an Egyptian selling hot Ta'amia and mukhalal from his cart to the rich and mighty tycoons of the American business world.

There was an insightful cartoon showing this kind of acculturation, which appeared in Al Akhbar newspaper some time ago just after the war in Afghanistan. I am sorry I don't have the exact reference. It pictured a starving Afghani warrior sitting alone on a mountaintop, watching American airplanes drop food packages. He got one of them and opened it, looked at the hamburger and shouted in dismay "so where's the catsup, Ya Kafirun?" (Ragab \& Hussein, c. 2001-2)

If we can so easily share and accept each other's food for the belly, why do we have such difficulty in accepting each other's philosophies, "food" for the soul?

This paper, then, presents an encouragement to look at different approaches to survival with tolerance and humor in an attempt to build understanding of different ways people attack the problems that face them. As Captain Mohamed "ما حدش احسن من حد" Latif used to say in his commentaries on football matches,

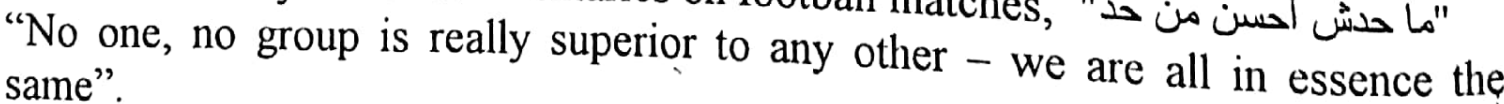

So now that we are on our way, let's look at what culture and tradition are: "The practices, representations and expressions, as well as the associated knowledge individuals, recognize as that communities, groups and in some cases, expressions and language; the performing arts; social practices, rituals, and 
festive events; knowledge and practices about nature and the universe; traditional craftsmanship (UNESCO, $32^{\text {nd }}$ Session).

Culture, traditions, heritage - the minute one begins to tread in these turbulent waters, there is always the exception to the rule to be found. Well, naturally. That's to be expected. After all, life is a dynamic force that is what being alive means. My father brought me up to believe that "there is nothing so permanent as change". Perhaps that is exactly where we are going in this discussion. Some societies, more than others, relish this exciting alteration of inherited characteristics, this rebellion from the pathways of the past, this crushing of things traditional to bring forth something always new and different, startling and anti-establishment. It was the American manufacturing and industrial production managers who coined the economic phrase "planned obsolescence". Nothing lasts forever. Buy something new, use it for a year or two, throw it out and get something different, more advanced. As with computers today, they are old and slow after six months, as newer models with better functionality appear on the market.

Other societies build to last through eternity.

So, let's take an historical overview of the cultures which evolved from the experience of the peoples we are examining today and let's see if we can come up with an understanding of the "how" and "why" they developed along the lines which shape their character to the present time.

We need to begin with Egypt and the Egyptians, that ancient people who created one of the world's oldest civilizations. Picture groups of people who seemed suddenly to appear with the dawn of recorded history, some 7000 years ago. History they recorded; history to last unto eternity. It was they who developed reading and writing and the material papyrus on which to write. Papyrus from which the modern day English word "paper" derives. How different from other parts of Africa where it is said that "if an old man dies you lose a library!" (Hampate, 1997)

The Egyptians are a homogeneous people. A simple, orderly agricultural people, they were experts in water and land conservation, never building their living quarters on arable land.

They were skilled physicians. Sports and athletics, music, dance and the arts attained very sophisticated levels of development. 
They mastered the sciences of astronomy, mathematics, chemistry, and with it the art of embalming, preservation from oblivion; and engineering, erecting temples and tombs to last through time. And this seems to be the very nature of their identity, to persevere through eternity, both in this world and in the next.

And it was here, in the Valley of the Nile, with "the surrounding desert, which gave Egypt its physical unity and was also a constant reminder to the valley inhabitants of their special dependence on the beneficent influence of nature" (Ions 1968) that these richly creative and powerfully inventive people devised an understanding of the world, not only in the physical sense, but also with a deep spiritual link. They contemplated their sheltered space introspectively and believed that Misr Um El-dunia, Egypt is the mother of the world

All through Egyptian history runs the thread of a profound spiritual awareness. "The boundaries between religion and what we should nowadays call politics were ill-defined. In so far as Church and State can be distinguished in ancient Egypt, it is clear that they supported each other" (Ions, 1968). Theological and laic law so entwined was not to be doubted or refuted. With it came a respect for the glorious past, their identity tied up with their heritage, respect for age and the wisdom it brings. The temples were seats of learning and the priests were the mentors of society. Religion defines the people.

And so, the Egyptians strong in their heritage were able to absorb and Egyptianize both immigrants and new ideas: both marauding invaders and the advent of Christianity and Islam. There was great tolerance and non-violence evident in the heritage of the Egyptian way of life.

In modern times, when King Farouk and his family were sent into exile after the near bloodless revolution in July 1952, the Egyptian nation sent them off in their royal yacht with much of their wealth and a 21-gun salute.

The American Revolution of 1776, on the other hand, was a very bloody affair, pitting brother against brother and sons against parents. The Civil War, fought over the economics of slavery and the possible dissolution of the Union some 74 years later in the mid $19^{\text {th }}$ century, was even more brutal, causing 600,000 deaths and a prolonged period of severe racial discrimination and intolerance.

So, with this brief look at the Egyptian past, we go on to look at America. We know where the Americans, immigrants all, originated. They have come from all over the globe starting with the first settlements in North America in1607, just some 400 years ago. They came mostly to forget where they came from, to escape tyranny and religious persecution, economic hardship, starvation and 
class abuse. They came to become; they came to look to the future not to revere the past. They came to The New World.

They came hungry to earn what was withheld from them in their own countries. They came to be free of the old prohibitions on behavior and thought which controlled their lives; they came to live in a society that separated theology from government, to live in a secular state. They came to experiment with new ways, to participate in devising a new system of government, a government "of the people, by the people and for the people" (Lincoln, 1863). They came to be masters of their lives and to manage their own affairs without undue government impositions and direction. They came to feel the freedom to try something out, to fail, to get up and do it again, to test it out, to succeed.

The land they found spanned a continent with a spectacular variety in geographical aspect and weather conditions. There was no singular code of ethics nor of a common tradition to live by; everyone anyone met came from somewhere else, spoke different languages and struggled to find common ground in English, The newcomers did not become part of the local population. They almost obliterated it.

And always there was a new frontier to conquer, a distant place to reach and subdue (Turner, 1954). And when the immigrants got to the West Coast, to the end of the land, they fixed their eyes upon the stars and the new frontier became the conquest of space itself. In almost every aspect of their development, there is this need within their character to bridge that new frontier, be it in science, music, agriculture, dress, style, behavior. Change and move on.

The American character seems in a way to have been forged by individuals determined to survive in an alien environment on their own. It is as if the mountains they encountered, geologically new and rugged, sharp and imposing, were to carve their imprint on American culture, unsoftened, often rude, thrusting sharply upwards, powerful. US heroes are often described as "rugged individualists", larger than life; those who made it on their own, without help or support from family or clan or philosophic ideology.

They learned they could do almost anything they set their minds to which has led to the coining of that splendid but smug expression "American know-how", not depending on the old ways of doing things, but creating and developing. That does not leave much in the way of reverence for the "old ways" or of respect for other cultures.

Today, as many as 400,000 European-born scientists have taken their talent and drive to the U.S. in search of better funding, facilities and career opportunities. 
Why did they go to the States? This is what they say, as reported in the January $19^{\text {th }}$ issue of Time Magazine (Chu, 2004):

"Europe is a mess, a haze of overregulated and overcomplicated bureaucracies smothering the rare flames of true entrepreneurial brilliance".

"You had to file a four-page application to get a used computer (in Hungary), only to be rejected because of a mistake in paragraph 342 ".

"In Germany, the principle of reward for performance doesn't exist".

"I love my country. My dream is to have the lab from New York - with the American organization and technology - in Naples."

A very different attitude and landscape to the gentle curves of the windswept sand dunes, limited valley and the enduring values of the Egyptian experience.

But you see, the ancient Egyptians did have this vigorous energy, but now it is the Americans who exhibit what you might call "teenage behavioror", bursting with a culture of youthful energy and creativity, devoted to taking the present by their own hands into the future. The Americans have very little past, certainly no single thread of a shared past. Their unity comes from their patriotism. The Egyptians look to the present from the past. The American can only look from the present to the future.

Is it possible then to consider any lack of understanding between this very old and traditional nation and this very young upstart culture as something of a "generation gap"? with each needing to learn to understand where the other is coming from and where he intends to go, and how, in order to live and let live?

The minutr you pait your finger on a given tradition in one part of any country, someone will up and tell you, "no, that's not how it's done elsewhere". The Sa'id is different in some ways from the Delta; Georgia is not the same as New York. Nevertheless, I'll try to paint a fairly realistic picture of American culture today, before it changes to American culture of tomorrow; our little game of planned obsolescence! I think the operative word is indeed "change" for there is little of the past to cling to, and change often means control. The Native American - the Indians - lived, as did and do the Egyptians, in peace with nature; the American aims to control it. Change is hard for outsiders to come to terms with.

Change - Mr.Kerry's first speech after winning 9 states in his bid for the Democratic nomination said, "Change is coming to America", (BBC, 3/2/2004). 
Change - a great story, and a true one, of an elderly woman who, having all of her life worn a wig as part of her religious attire in the old country in Europe, sailed into the port of New York in 1907. "Upon seeing the Statue of Liberty standing proudly in the harbor, clutching the torch of freedom in one arm and a book in the other, symbolic of learning and justice, she flung her wig and the "old ways" it represented into the ocean. She went on to enroll in scheol to learn the new language, English, while raising her family in the new society, and graduated high school at 65 along with her 16 year-old grand-daughter.

Change - there is an American musical show called "Fiddler On The Roof" (Bock et al., 1964), which is a portrayal of typical eastern European life and its traditions - traditions without which their lives "would be as shaky as a Fiddler on the Roof". The play describes how their social and religious traditions affected every aspect of daily life, where everyone knew who he was and what was expected of him. At the end of the play, when the family is uprooted from their village in Russia and are about to embark on their emigration to the US, the younger children start getting rowdy and argumentative. The aggrieved father says to them, "Where is your respect? You are not in America, yet!"

There's a fine old Egyptian film, called "The Flirtation of Girls", with Naguib El-Rehany, Laila Mourad and Seliman Naguib that I love and I think has bearing on this issue of respect. Naguib El-Rehany has been employed to tutor Laila Mourad, the daughter of a rich Pasha. Shabbily dressed, poor, Naguib arrives at the Pasha's villa and encounters the well-dressed butler. He is overcome with respect for the butler whom he has mistaken for the Pasha. He can hardly speak and stutters obsequiously in answer to what his business is there. The Pasha, who's been gardening, comes in dressed in work clothes, and Rehany, thinking he is a servant, sneers at him rudely and most disrespectfully. Rehany here, as in many of his satirical comedies, intends to show how society, often hypocritical, depends on convention to judge people.

If you ask an Egyptian "Who are you?" the likely answer would be that he is the son/daughter of so and so, from this or that village, which shows enduring ties to the fabric of society. Ask an American and he'll tell you what his present profession/work/job is, which by the way, could change at any moment.

The forms of address tend to be less structured in America. Professionals as well as laborers are often simply called by their first name. I sometimes even now wonder why my husband of 47 years calls me " $Y a$ Madame"!

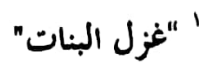


A friend of mine, Nabila, ignored me for six months after she had been to my house for tea. Finally, I asked her outright what the matter was, and she said, "You closed the door immediately as I left your house as if you couldn't wait to get rid of me." It is funny, that now when I go to the States and my hosts do not wait at the elevator with me or keep the door open until I have gone, I feel slighted.

My children asked me early on that although they would never smoke in front of their father, would I mind if they smoked in front of me since I was an American.

On the other hand, it is very difficult for the American to accept the concept of "Ma'alesh", mired as it is in the surrender of one's control over his environment.

That is not to say that Americans do not have respect for anything. Indeed, they do. But, by and large it is respect that the individual, the leader, the teacher, the boss, has earned, not gained through parentage or connections, seniority or tradition; respect for work well done.

There is respect for parents, family and children through a sense of responsibility. There is respect for the rules and regulations that make daily life more manageable. There is respect for traffic regulations and laws governing damage of property, for attendance at school; respect for other people's right to peace and quiet, respect for the courts of law where people are judged by a panel, a jury, of their peers.

Taxes are not negotiable; quality and quantity of work are not negotiable; building codes and manufacturing standards must be adhered to. Time is a fixed concept not a relative dimension.

On the other hand, Americans may not necessarily respect their politicians or political authority, or religious mores. On February 19th this year, there was a demonstration concerning the legality of homosexual marriage with San Francisco for and Mr. Bush against. One of the demonstrators yelled: "Civil disobedience is what this country is all about" (BBC, 2/19/2004).

However, life is a paradox and many exist in the American way of life.

America is a veritable "Melting Pot", a country in which a blending of races and cultures has been and is taking place. It is a country constitutionally established with the principles that "all men are created equal", an equality of opportunity to "life, liberty and the pursuit of happiness" (US Declaration of Independence, 1776). And yet, you find a society that has discriminated severely against almost 
all segments of its population at one time or another. Discrimination has been rampant against the blacks, Irish, Chinese, Catholics, Jews, Hispanics, and women; any newcomer is fair game. There is residual personal intolerance running deeply through the fiber of the American psyche, sometimes to the point of xenophobia.

- It is a country with strict observance of the separation of church and state; and yet, at the beginning of the school day, for example, children pledge their allegiance to the country, remember, a country united by patriotism, saying, "I pledge allegiance to the United States of America and to the Republic for which it stands, one nation, Under God, with Liberty and Justice for All". On US currency, the greenback reads "In God We Trust" and a large part of the middle section of the country is politically referred to as "The Bible Belt", a very conservative and religiously oriented population.

This is, perhaps the profound difference between Egypt and America, between East and West; the one spiritual, where the relationship to God is found in almost every thought and every utterance, Insha Allah, Alhamd Allah, Masha Allah, Rubbina Ma'ak, etc. It is a part of every day living, of life itself. Whereas, in the US, religion is just that, it is faith in the Almighty, pervasive, but not intrinsic

Egyptians then, are spiritual and steeped in the traditions of over 5000 years, friendly, tolerant and easy-going but highly class-structured, with close family interdependency, lax about secular law and precision, casual about time and time management.

Americans, on the other hand, are still defining their culture, secular and antiestablishment; keen to obey secular law but willing to change it; tolerant of differing ancestry, but often ignorant and intolerant of foreign cultures, with strong but independent family relationships, punctilious in their work ethic, obsessed with time to the point of almost worship.

How can the people of these two disparate cultures, one homogeneous, the other heterogeneous, similar in their spiritual and material needs, in their bonds to family and friends come to understand each other, to come to terms with their otherness?

Two verses in The Holy Koran, Sura Al 'Alaq (96) and Sura Al Kafirun (109) are incisive:

The very first verse of the Holy Koran, Sura Al 'Alaq, (1-5) (Iqraa): 


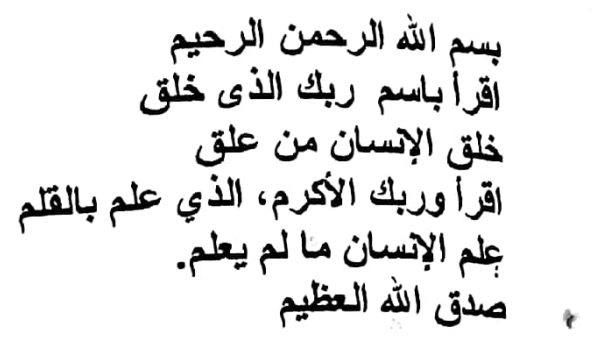

Read

In the Name of Thy Lord and Cherisher, Who Created

Created man, out of a (mere) clot of congealed blood

Proclaim! And thy Lord Is Most Bountiful

He Who taught (the use of) the Pen

Taught man that which he knew not

Education - reading and writing in all spheres of knowledge is blessed. Education stimulates empathy for the way each individual approaches his world. That does not mean that the weaker nation should change its culture for the more powerful. No Corn Flakes instead of Foule Madames, no coke instead of assir qassib. We should be able to accommodate to our differences and revel in their variety and beauty and individuality.

Just a momentary diversion, if you will allow me. I think that for two peoples to come together in peace and harmony, each must be secure in his culture. And so I think that language schools in Egypt do a disservice to the nation by not thoroughly grounding and involving their students in the Arabic language and hence its culture. Each subject should be taught in Arabic and the foreign language taught solely as that, a foreign language. "Mother tongue languages should be favored in educational systems from the earliest age" (Matsuura, 2004).

Mahatma Gandhi said and I quote: "I do not want my house to be walled in on all sides and my windows to be stuffed. I want the cultures of all the lands to be blown about my house as freely as possible. But I refuse to be blown off my feet by any. I refuse to live in other people's houses as an interloper, a beggar, or a slave."

The media can also play a valuable part in helping cross-cultural understanding, but there is a need for honesty and transparency. However, if the shows contain historical or other errors, they can do terrible damage. Witness Cecil B. De Mille's film, The Ten Commandments, produced in 1956: in telling the story of the building of the first pyramid, it erroneously put the time frame of the film in the New Kingdom and showed that the Egyptians were cruel taskmasters, who whipped the Jews used as slave labor. In fact, the pyramids were built in the 
Old Kingdom and most of the labor used was Egyptian farmers idle during the times of the Nile flood. The twelve tribes of Israel had not yet entered Egypt. The film is a travesty of historical fact and has probably led to a lot of rancor.

We all need to have access to honest reporting and to read widely, to broaden our horizons and to avoid parochial thinking.

The other early Meccan Sura that I urge you to think about, Sura Al-Kafirun, advises tolerance and acceptance.

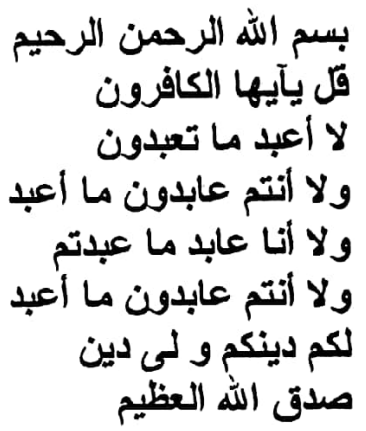

Say: O ye That reject Faith!

I worship not that Which ye worship

Nor will ye worship That which I worship

And I will not worship That which ye have been Wont to worship

Nor will ye worship That which I worship

To you be your way And to me mine

In matters of Truth we can make no compromise, but there is no need to persecute or abuse anyone for his faith or belief.

In conclusion, I should like to leave you with an experience that both illuminated and thrilled my mind. Last January, an Egyptian colleague and I were preparing a few paragraphs on the history and facilities of the new Library and Convention Center of the Faculty of Agriculture at Cairo University. The last sentence I wrote, concerning the impact the founders of the Library intend to have on the student, was "Knowledge is Power". My colleague edited the sentence to read, "Knowledge is Virtue".

I decided I might try to find out where his thinking had originated and I was enlightened. Virtue is Fadila; his approach to the whole marvel of man's ascendancy in the world is spiritual, as revealed in The Holy Koran. Whereas I - after having been in this country as wife and mother for over 45 years; having 
eaten of its legumes, melons, garlic, lentils, onions ${ }^{2}, \mathrm{I}$, without hesitation, quoted from Francis Bacon, a British philosopher who described a utopia established on scientific principles, the secular rather than the spiritual.

The happy ending is that my colleague, Mohamed, and I married both philosophies together, the secular and the spiritual, and came up with the concluding sentence that "knowledge itself is both power and a virtue" (ElMohandes \& Selim, 2004).

So, again, let's look at Kipling's Ballad with the lines concluding the verse:

"Oh, East is East, and West is West and never the twain shall meet, Till Earth and Sky stand presently at God's great Judgement Seat, But there is neither East nor West, Border, nor Breed, nor Birth, When two strong men stand face to face, Tho' they come from the ends of the earth!"

Yes, cultures do and will always differ. And this diversity is creative. But at the same time, all men are brothers when they recognize their common humanity in mutual respect, in love and in courage, in bravery and in loyalty and in truth.

Perhaps, then, the twain can meet, to develop a continuing dialogue face to face, come together and join hands with deeper tolerance and understanding, to help make this a better and happier world.

2من بقلها وقتائها وفومها وعدسها وبصلها (البقرة: (7) 


\section{ACKNOWLEGMENTS}

Thanks to the USA for the opportunity of a superb education, independence of spirit and close family and friends.

Thanks to Egypt and my Egyptian family and friends for accepting me, enfolding me lovingly in their culture, affording me a gentle and happy life.

\section{REFERENCES}

The Holy Koran: Sura Al 'Alaq (96) 1- 5; Sura Al Kafirun (109); Sura Al Baqara (61).

Ali, A. Y., The Holy Qur-an, Text, Translation \& Commentary, Vol. 2, Shaikh Muhammad Ashraf, Kashmiri Bazar, Lahore, Pakistan, 1938, pp 1761-1762, 1799-1800, 32 .

Bacon, F., \{nam et ipsa scientia potestas est\} Meditationes Sacrae, 1597.

Bock, J., S. Harnick and J. Stein, Fiddler On The Roof, Sept. 22, 1964, a musical play based on the short story, Tevye and His Daughters, by S. Aleichem.

Brewer's Dictionary of Phase and Fable (rev. by I. H. Evans), Centenary Ed., Harper \& Row, Publishers, New York and Evanston, 1970, pp 361.

BBC World News, TV, 8.20 a.m., February 19, 2004.

BBC Woild News, TV, March 2, 2004.

Chu, J., How to Plug Europe's Brain Drain, Time Magazine, January 19, 2004, pp.32-39.

De Mille, C., The Ten Commandments, Paramount Pictures, 1956.

El-Mohandes, B. and M. Selim, The Abstracts Booklet, $3^{\text {rd }}$ African Acarology Symposium, 11-15 January, 2004, Faculty of Agriculture, Cairo University, Giza, Egypt, p. 5.

Gandhi, Mahatma, http://web.mahatma.org.in/quotes.jsp?link=qt 
Hampate $\mathrm{Ba}$, Website UNESCO, The Routes of Andalus place of encounter for intercultural dialogue, Granada, Spain, 27-30 Sept.,1997

Ions, V. Egyptian Mythology, The Hamlyn Publishing Group, Hamlyn House, The Centre, Feltham, Middilesex, 1968.

Kipling, R., The Ballad of East and West, 1899, www site Copyright 2003-2004, $<$ readbookonline.net>.

Lincoln, A., The Gettysburg Address, given at a battle field near Gettysburg, PA, USA, Nov. 19, 1863.

Matsuura, K., Director General of UNESCO, Feb. 19, 2004, International Mother Language Day Message.

Ragab, A. and M. Hussein, Al Akhbar newspaper cartoon, c. 2001-2002, Egypt.

Turner, J. F., The Importance of the Frontier in American History, from the Annual Report of the American Historical Association, 1893, The Making of American History; Book One: The Emergence of a Nation, (Ed. By D. Sheehan), Holt, Rinehart and Winston, New York, 1954, pp. 193-222.

UNESCO, Intangible Cultural Heritage, $32^{\text {nd }}$ Session, General Conference of UNESCO.

United States Declaration of Independence, July $4^{\text {th }}, 1776$. 
Barbara L.El Mohandes

English Language Consultant, Parasitic Acarine Project \& PARC, Faculty of Agriculture, Cairo University

The First International Conference of The Faculty of Al-Alsun, Minia University Egypt in World Literature

14 - 15 April 2004

\section{Abstract \\ Is it true that East is East and West is West and never the Twain shall Meet}

"Oh, East is East, and West is West and never the twain shall meet, Till Earth and Sky stand presently at God's great Judgement Seat" from The Ballad of East and West, by Rudyard Kipling. Rudyard Kipling was a British author and poet born in India in 1865 but raised with a thoroughly British education: a denizen of two disparate worlds. He interpreted India, the army and British imperialism, won a Nobel Prize in so doing, and therefore his writings most probably reflect a great degree of truth about the societies of east and west in Kipling's time. Quoting from Brewer's Dictionary of Phrase \& Fable, "this is a phrase (from the poem) which emphasizes the divergence of views on ethics and life in general between the Oriental and Western peoples". Does this dissimilarity, indicating an essential lack of resemblance between things in some respects comparable, exist between Egypt and America, today?

In this paper, the author hopes to encourage a questioning of what certain habits, customs and traditions mean to each of these two societies and how they may have originated. Why is there such a disparity-in each society's approach to the perception of the human condition and in its reactions to the world around them? Discussion will be based upon the immense differences in the age and origin of each nation, in their attachment to either spiritual or laic philosophy, geography and historical experience and their conception of time itself. Some amusing, it is hoped, examples of differing habits, customs, traditions are included.

From this discussion and the incidents set forth, can we hope to gain, at least, a deeper understanding of each other's ways of coping in an uncertain world? Can we attain empathy to our differing approaches in dealing with society's problems? Can we develop a certain flexibility in judgment of and indulgence for each other's foibles, in order to reach a more comfortable and peaceful relationship? The author would be pleased to have an unqualified "yes" in answer to all of the above; yes, it is all in the realm of the possible, and the "twain" can meet on common ground. 


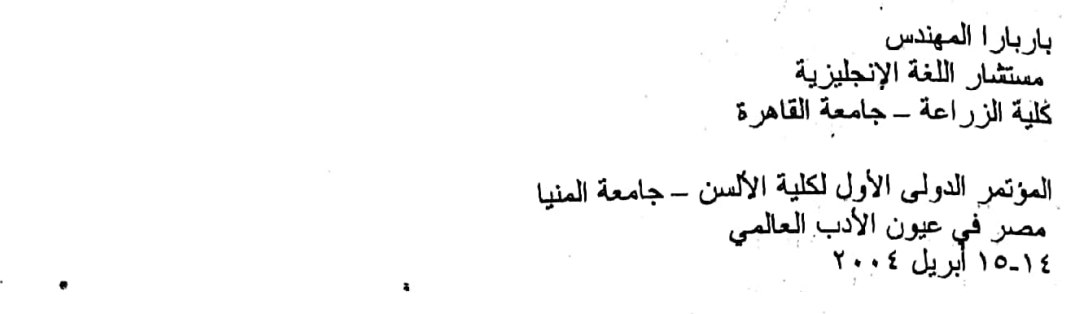

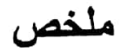 \\ هل حقيقي أن الثرق سيظل شرقاً والغرب غرباً وأنها أبداً لن يلتقيا}

"إن الشرق سيضل شرقاً والغرب غرباً ولن يلتقبا الاثثان أبداً ، حتى تجتمع الســـاء

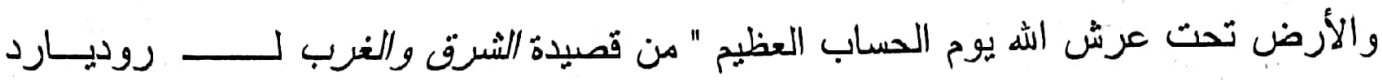

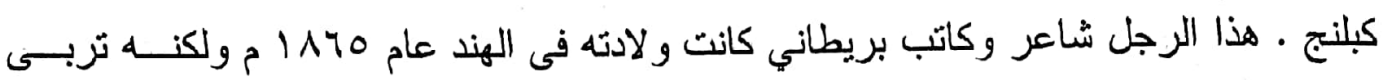

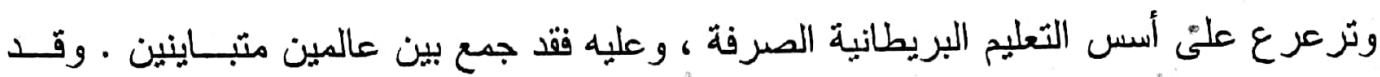

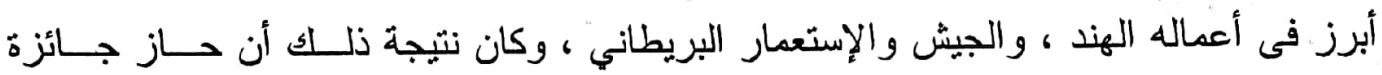

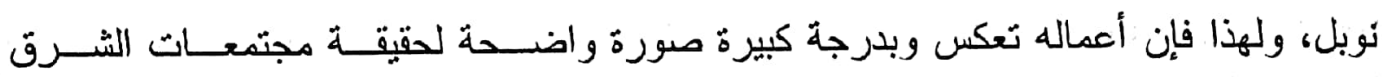

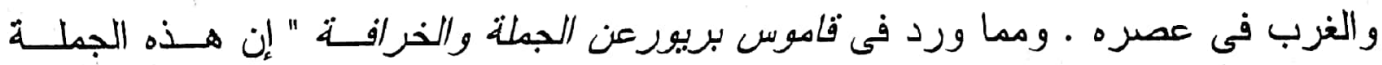

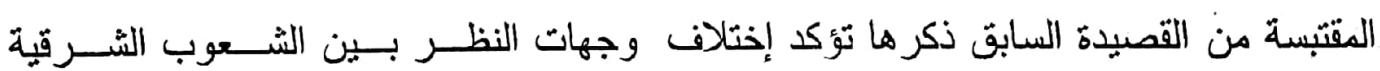

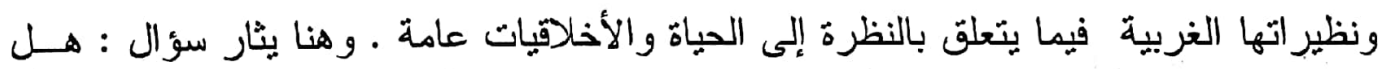

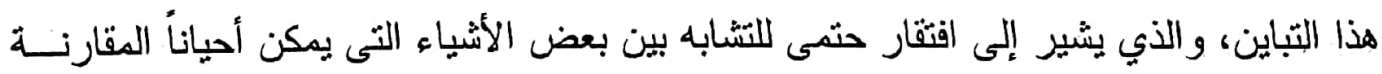

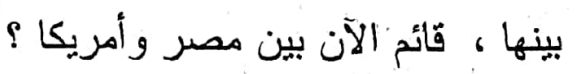

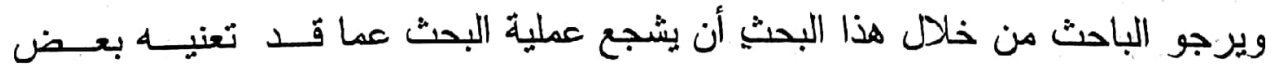

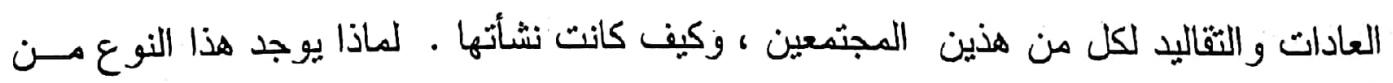

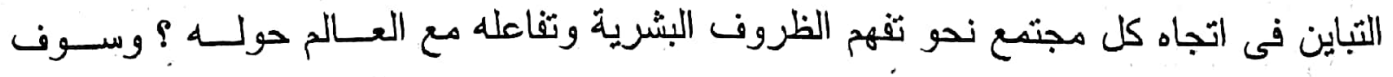

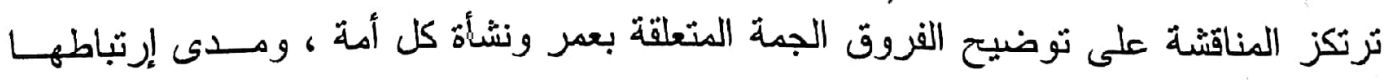

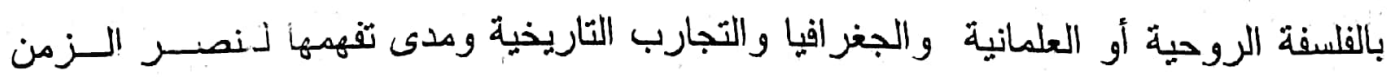

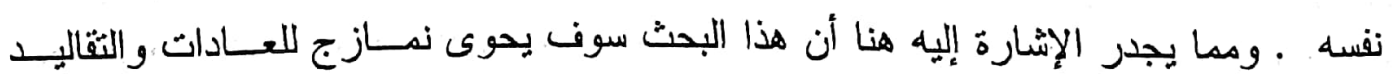
المختلفة والتى هى ذات طابع دميز يجذب إليها الأنظار.

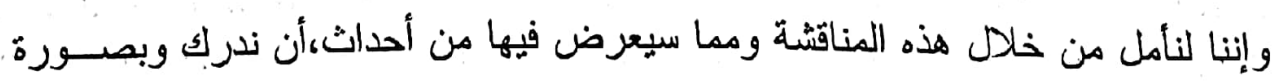

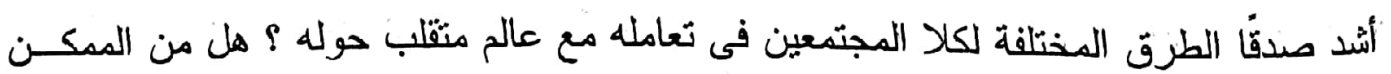

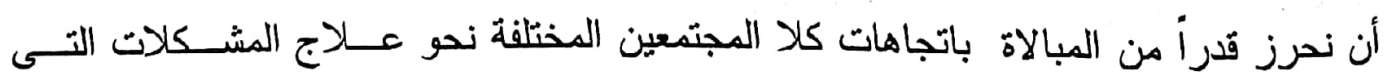

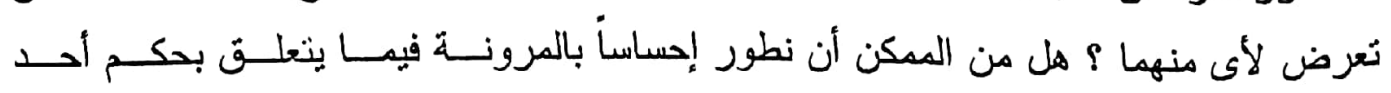


المجتَعين على نقاط ضعف الآخر وغفرانها ، ونلك حتى يكون من المكــن إرســاء دعـانم

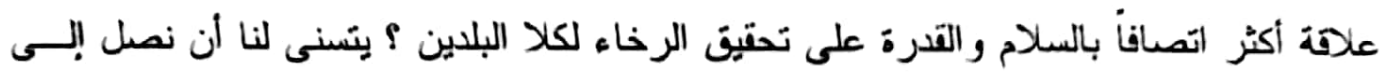

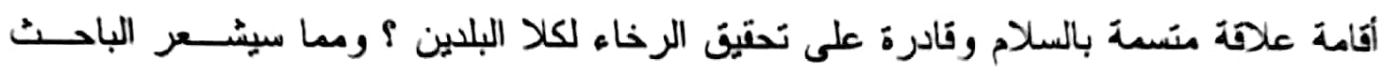

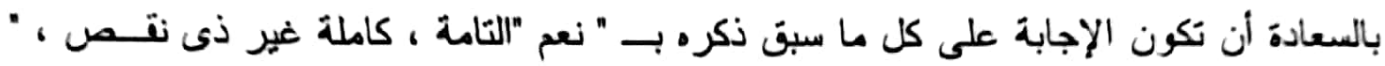

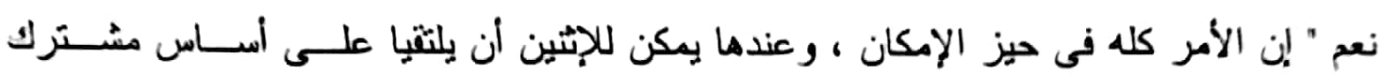

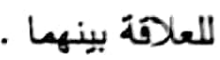

